\title{
Gender, Race, and Male Privilege in Post- Modern Society
}

\author{
By Richard D. Christy*
}

The literature in sociology and the current discussions in the media, identify a growing crisis in modern masculinity. Various social indicators support this claim. At the same time, there is an enduring assumption that males in post-modern society live lives of privilege. In a social era increasingly based on achieved status some males succeed, others fail, and not all males are equal. What are the social and cultural changes in gender and race? Is it possible that the social script for boys, young men and men of all racial groups prevent them from succeeding in post-modern Canada and the United States? Have males inherited a "male code" inappropriate for the "information society"? Kaufman argues in Cracking the Armour that "the old rules of the game have broken down. A genuine profound crisis of masculinity is sweeping North America and Europe and is beginning to reach to the rest of the world"(Kaufman, 1993) What is the emerging picture of male privilege when you examine men and mortality rates, life expectancy, men and violence, unemployment rates and graduation rates and post-secondary education?

Keywords: male domination, male privilege, men and violence, "whiteness", misandry.

\section{Introduction}

Few topics in sociology are more controversial than gender, race and economic inequalities. Many researchers conclude that social and economic inequalities are the result of institutional patriarchy, capitalism, racism and globalism. Research on social injustice and economic inequality primarily focused on women, visible minorities, and indigenous people. What would be the sociological conclusions if males and male privilege were the focus of inequalities?

Sociologists have considered social inequality in gender and race at the societal level using structural functionalism, conflict theory and Marxist analysis. What would sociologists conclude focusing at micro and group level using Max Weber's interpretive perspective? While Weber never directly considered gender and race, stratification, status and power, each essential variables in understanding social inequality and privilege were at the heart of his work. Weber concluded from his broadly based historical analysis that societies were always coming together, falling apart, shifting and changing. Collins and Makowsky (2010) argue that for Weber "history shows nothing permanent but continual war, conflict, and change" (Collins and Makowsky 2010: 109).

According to Weber, groups of people who associate together are the basic unit of society. Since Weber, researchers have concluded that in "face-to-face groups that people acquire their identities, their values, and their world view" (Weber 1947: 109). Groups are very different and as Weber agued it is an error to

*Associate Professor of Sociology, Wilfrid Laurier University, Canada. 
suppose the values, the norms, the beliefs, reputation, status and reputation of one group sums up the position of the whole group. Mindful of this conclusion, can sociologists assume that all males are equal or that privileged, white males necessarily represent all white males? Not all males are equal and privileged just as we cannot assume that all women, blacks, or other minority groups do not have privileges. Weber it is not enough to identify social regularity but it is essential to understand the meaning behind social action. For Weber it is not enough to know the percentage of university students who smoke or the percentage of a population that vote. Sociologists must ask what is the social meaning of smoking or voting for an individual or a group? Weber (1947) reasoned that "action is social in so far as, by virtue of the subjective meaning attached to it by the acting individual or individuals" (Weber 1947: 88). Weber argued that so much of action is routine, self-evident and spontaneous it necessitates "clarity and verifiable accuracy of insight and comprehension" (Weber 1947: 90). Therefore, do researchers must examine the subjective meaning of gender and race?

It appears that the public discourse and the rhetoric of advocate groups assume the realities of male social roles are one of dominance and privilege. It may be an irrefutable fact that in traditional societies, many male lived lives of status and privilege. However, was this true for all men? Is universal male privilege a historic fact and a modern reality? To "understand" social status, Weber defined ethnicity and race. He described ethnic groups as "those human groups that entertain a subjective belief in their common descent" (Morning 2016: 241). According to Morning, Weber considered it essential to define ethnicity and race in understanding group formation, status and behavior. I consider it equally essential to understand gender and race if we are to understand men, masculinities and male privilege in modern society.

\section{Towards an Understanding of Gender and Race}

Embodiment is a starting point for the subjective understanding of gender and race. Watson (2000) states that embodiment is how men experience everyday life. Watson argues that the issues of men and health but also "perhaps men's place in society, is crippled by the lack of attention paid to personal accounts and perception of maleness" (Watson 2000: 4). In Male Bodies: Health, Culture, and Identity, Watson recognizes embodiment because "within the parameters of professional understanding, male embodiment remains largely 'unproblematic', fixed and immutable" (Watson 2000: 5). He notes that researchers write as if men are an abstraction or an invisible entity, existing outside the concrete material world. His analysis of life expectancy by sex and country; suicide rates and gender; death rates by age and class; and causes of death by gender, indicate that embodiment and maleness is problematic and gender and race is neither fixed nor immutable.

In his analysis of masculinity, Morse (1996) writes that "stereotypes came into their own with the modern age as part of a general quest for symbols in order to make the abstract concrete within the bewildering changes of modernity" 
(Morse 1996: 5). The idea of modern masculinity emerged "between the second half of the eighteenth century and the beginning of the nineteenth" (Morse 1996: 5). The human body took on a symbolic form and "modern masculinity was to define itself through an ideal manly beauty that symbolized virtues" (Morse 1996: 5). The criteria of the stereotypical male was wealth, social and political status, physical health and beauty. For Morse male beauty and privilege was and is an ideal, a social construct and open to change. Today according to Morse, "there (is) no longer much talk about fashioning a 'new man' who would guide the nation into a higher future" (Morse 1996: 4). There is little interest in honoring and celebrating men or masculinities. There does appear to be interest in marginalizing all men, White, Blacks, men of Color, Gentiles, Jews and Muslims. The extent to which this reluctance to celebrate men is true, there is a growing crisis in masculinity.

\section{The Crisis in Masculinity}

Since the 1960s, there is a reluctance to ask questions about the inequality and discrimination facing men. Could all men, white, black and males of color be experiencing downward social and economic mobility?

In 1993 Farrell, twice elected to the Washington based National Organization of Women, challenged the existing assumptions of masculinities in The Myth of Male Power. Farrell questioned the universal assumptions of male privilege and power. By introducing statistical data on health, suicide rate, and life expectancy, Farrell's findings on men of all age groups, ethnicity, levels of educational levels and race challenged the existing public dialogue of gender inequality, dis crimination, and illustrated that men's lives are not necessarily privileged.

Corneau (1991) writes in his book, Absent Father, Lost Sons: The Search for Masculine Identity, that Dr. Hubert Wallot in his testimony before a Canadian parliamentary commission on mental health that the Canadian government establish a council on the status of men to deal with "the precarious condition of men's health" (Corneau 1991: 1). Wallot noted "four times as many men suffer from alcoholism and drug addiction as do women; they also outnumber women three to one in the area of suicide and high risk behavior" (Corneau 1991: 2). This data suggested to Wallot that men have medical, emotional and social problems that required attention. For Corneau Wallot's statistics, data indicates the males are facing an identity crisis and there is a need to understand the social, emotional and economic issues facing men. In The Crisis in Masculinity, Leanne Payne (1991) argues there are a "great number of men, who to one degree or another are insecure in their masculinity" (Payne 1991: 11). She "point out some of the causespsychological, historical, and philosophical- of this growing cultural malady, already near epidemic in proportions, that I have called the crisis in masculinity" (Payne 1991: 11),

In a similar manner, Kaufman (1993) writes that there is a new confusion in the lives of men since the 1960's that "called into question men's assumption about power, and identity, about what it means to be men" (Kaufman 1993: 5). For 
Kaufman the rules that guided gender relationships no longer exist and "a genuine and profound crisis in masculinity is North America and Europe and is beginning to reach out to the rest of the world. It is a crisis that touches the lives of every one of us" (Kaufman 1993: 6).

By contrast, Kahn (2009) takes the position that male privilege does exists. He concludes, "privilege can be thought of as an unearned social granting of a route to accessing cultural resources" (Kahn 2009: 26). For Kahn privilege is the positive advantages to an individual who belong $s$ to specific group, community or society. Kahn is "primarily concerned with male privilege, which means that as a function of being or presenting as male, certain opportunities, activities and resources are made more accessible to you than to others" (Kahn 2009: 27). If privilege is a reality for all males, and particularly for white males, what is the essential nature of becoming and being white?

\section{Is White a Color? Race and Constructing Social Norms}

According to Morning (2016) "the race concept - people's belief about race, including their notions of which groups are races and who belongs to which race has emerged in different forms at different times, or perhaps not at all" (Morning 2016: 246). Morning agues "there is nothing natural or inevitable about the way human beings have created racial categories; the conventions and classifications we come up with are reflections of the social, economic, and political worlds we live in" (Morning 2016: 247). For example, Frankenberg wrote in The Social Construction of White Women, Whiteness Race Matters that as a white feminist she found that "race, like gender, is 'real' in the sense that it has real though changing, effects in the world and real tangible, and complex impact on individuals' sense of self, experiences, and life chances" (Morning 2016: 11) Frankenberg argues that for her race is socially constructed. For both Frankenberg and Morning, "whiteness" is not always obvious. To understand "white" as racial category individual men and social groups of men must acquire a consciousness of their color.

In Perry's research on race among high school students in California her "working assumptions, mainly that all identities spring from social relations and that one needs to confront a 'racial other' for there to be a 'racial self" (Perry 2015: 438). She assumed that white students attending an urban multiracial high school would reflect upon their whiteness more than whites at less diversified suburban schools. She observed that in the multiracial school, white youth stumbled to answer the question "What does it mean to be white?" Perry found "some felt victimized as whites, some felt privileged, and many felt both. Some felt 'racist' some felt 'nonracist', many felt both" (Perry 2015: 438). Perry found that in the multiracial high school and the suburban high school, white students found it difficult to describe white American culture and the "themes and characteristics of white culture that youth expressed included heterogeneous, middle-class, commercial/consumerist, American normal, and taken for granted" (Perry 2015: 451). 
In Fordham and Ogbu's article "Black Students' School Success, Coping With the "Burden of 'Acting White" they discuss the dynamic of blacks and whites culture in a high school population in Washington D.C. that is $90 \%$ black. If Black students pursue academic success, the student risk the loss of social identity for "being kind of white" as two Black students Sydney, a popular male underachieving student and Katrina, a popular female high-achieving student, learned. Each student developed strategies for not "acting too white" to reassure other students of their black loyalty and identity. Students achieve "this group loyalty by defining certain attitudes and behaviors as 'white' and therefore unacceptable" (Fordham and Ogbu 2015: 367). For those Black students personal achievement had to be balanced with such perceived unacceptable "white" activities as listening to classical music, reading or writing poetry, going to the opera, speaking correctly or studying at the library.

For Perry (2015), Fordham and Ogbu (2015) racial social identity, and racial distinctions is fluid and complex. Perry challenges the assumption "to see white identities and attitudes as fixed and stable" (Perry 2015: 340). Perry concludes there are "shades of white", and there must be "shades of white privilege males"?

Kwan- Lafond (2012) advocates for a critical examination of white privilege and states, "not all white people are equally privileged and not all people of color are oppressed in the same way" (Kwan- Lafond 2012: 227). According to Bell Hooks (2004) "many men in our society have no status, no privilege, they receive no freely given compensation, no perks, with capitalist patriarchy. ..... These men suffer. Their anguish and despair has no limit or boundaries. They suffer in a society that does not want men to change" (Hooks 2004: 138). Hooks argues that many men are unable to speak of their suffering for fear that their exposed weakness will challenge their manhood and their weakness will be used against them by other males and by radical feminists who are "so enraged by male domination that they cannot acknowledge the possibility of male suffering or forgive" (Hooks 2004: 139).

Nathanson and Young warn that since the 1980's there is a pervasive misandry in popular and argues that "many would be shocked to realize how profoundly their own thinking has been influenced by ideology, the influences being so subtle that it would hardly seem possible" (Nathanson and Young 2001: 237). Greig and Martino grasp this trend and describe men and masculinity as the "new disadvantage". They dismiss comments of a "backlash and result of changing structural and institutional relations of inequality that have arisen in response to the impact of globalization and deindustrialization" (Greig and Martino 2012: 1) or "antagonistic to feminism and pro-feminist perspectives" (Greig and Martino 2012: 2). They draw attention to the necessity of discussing the new disadvantaged "despite the current debate over men and boys, white, affluent, heterosexual males [remaining] relatively privilege, economically, socially, and politically, compared to their female counterparts"? (Greig and Martino 2012: 2). Knuttila (2016) in Paying for Masculinity uses the title of the 1966 movie The Good, the Bad and the Ugly to describe "how men and boys behave, how we are perceived and how we are represented.....yet men also often suffer loneliness, feelings of isolation and the lack of intimacy and close 
friendships" (Knuttila 2016: 1). While Knuttila (2016) identifies the contradictions in the public and private lives of men, he declares without qualification on the cover of his book that men commit crimes, men are violent, men start wars and men have power. While many men have power and privilege that is not the entire story. Do some men have more power and privilege as others do? What are the indicators of male privilege?

\section{The High Cost of Gender and Race in Men's Lives}

What can we conclude about men and male privilege from an examination of mortality rates, health and wellness, death by violence, education and unemployment? According to Kaufman, the former rules in gender relations have broken down and men have had to adjust to new reality and to "all the joy and pain of manhood are now joined by a new confusion" (Kaufman 1993: 5). Could it be possible that indicators of this confusion are identified in the statistical findings of the social and economic data in men's lives? Is there a disconnection between the assumptions of privilege in men's lives and data on gender differences?

\section{Mortality Rates: Gender Gap}

According to Perls and Fretts (2002) in 1990 life expectancy in the United States 79 years for women and 72 years for men. Over the years, life expectancy for men and women has changed "the average national life increase in life expectancy in developed countries has been $71 \%$ for women and $66 \%$ for men" (Perls and Fretts 2002: 105). Researchers expect some decline in women's gain in life expectancies in that "more women have taken on behaviors and stresses that were confined to men - smoking, drinking, and working outside the home" (Perls and Fretts 2002: 105).

Lindsey's (2011) comparison of mortality rates (number of deaths X1000) to morbidity rates (amount of disease and illness). In a given year in the United States "women have higher morbidity rates but live longer than men, men have lower morbidity rates but do not live longer than women" (Lindsey 2011: 39). Lindsey also observed in the United States that of the top 15 causes of death, males have a higher rate with the greatest differences in non-disease deaths, suicide at 4.1X, homicide at $3.8 \mathrm{X}$, and accidents at $2.2 \mathrm{X}$. The mortality rate between men and women is narrowing but "the age-adjusted rate for men is still about $40 \%$ greater than for that of women" (Lindsey 2011: 40). The life expectancy in term of gender and race indicate that white females at birth have the highest life expectancy, followed by African-American females. "White males are gaining, and they reached parity with African-American females in 2000 .....the gap reappeared within two years and is again widening" (Lindsey 2011: 40).

Life expectancy of Black males at birth is the lowest life and in 1970 at age, 65 white and Black males had the same life expectancy. By the mid 1980's a gap began to appear between White and Black males at the age of 65 . The life 
expectancy for 2010 and 2050 from the United States Census Bureau, predicts that white male expected to live until 81.2 and Black males 79.1 years. By contrast, life expectancy for White and Black females will be 85.5 and 84.3 respectively.

According to Statistics Canada (2015), life expectancy rates from 1920 to1922 were 59 years for males compared to 61 years for females virtually the same. The gap widened to 5 years in 1980-1982 with life expectancies for males at 72 years and females at 79 years and in 2007-2008, the gap was 4 years with life expectancy for males was 79 years for males and 83 years for females. On provincial bases, the lowest life expectancy for males is 77 years in Newfoundland Labrador, Manitoba, and Saskatchewan and the highest life expectancy for woman at 84 years in the provinces of Ontario and British Columbia. If longevity life is a privilege that in the United States White and Black women have higher prestige than White and Black males and in Canada woman have higher status than males since the 1920s.

\section{Men and Violence}

Any topic of men and masculinity eventually turns to hegemonic males characterized by violence, aggression, stoicism, sexism and racism. Knuttila (2016) argues "in so-called common sense narratives and discourse, is that men are violent, just plain violent, likely as a result of their biology or genes" (Knuttila 2016: 127). For Knuttila the issue is more perplexing and complicated but for obvious reason the public discourse on gender violent comes to this conclusion since " $80 \%$ of the victims of intimate partner violence were women, as were $81 \%$ of spousal violence victims" (Knuttila 2016: 130). By contrast "males on the other hand are more often than women in the categories non-intimate partner, friends, casual acquaintances, close friends, and criminal associates, authority figures and strangers" (Knuttila 2016: 130). For example, Knuttila notes that in terms of physical assault, men are $8 \%$ more likely to be victims than females and from 2004 to 2008 "adult males were more likely than females to be homicide victims accounting for 74\% of victims" (Knuttila 2016: 131). Without minimizing violence against women by other women and men, a deeply rooted reality for men of all races is their fear of violence, physical assault and violent death.

\section{Unemployment and Gender}

The economics debate as it relates to gender and race has focused on women and such themes as pay equity, barriers to non-traditional employment, combat roles in the military, underemployment and access to education. However, the recession of 2008 brought into focus the unemployment of underemployment of males. Hennessy and Yalnizyan (2009) argue that commentators in the United States are "calling the recession, there a 'he- recession' because $80 \%$ of American workers whose jobs have been wiped out are men" (Hennessy and Yalnizyan 2009: 1) also in Canada "we're experiencing a he-recession of our own: $71 \%$ of 
Canada's unemployment victims in the recession thus far are men" (Hennessy and Yalnizyan 2009: 1). More specifically, $63 \%$ of male workers age 25 to 54 have lost their jobs and as the recession deepened more women over age, 55 are working and $70 \%$ of their jobs were full-time jobs. Lindsey (2011) notes that the American Bureau of Labor Statistics found that as "the recession moved in the end year in 2009 , men's unemployment rose at a faster rate $(2.8 \%)$ than the rate for women (1.6\%); over two-thirds of rise in unemployment has been among men" (Lindsey 2011: 285). Ferber (2004) uses this economic data to argue, "woman's inroads into the workplace, increased political and economic autonomy and the questioning of male domination have historically been perceived as threats to male privilege" (Ferber 2004: 228). Ferber goes on to argue, "in both academic and mainstream circles, the idea that masculinity, especially white masculinity is in crisis is widespread" (Ferber 2004: 228). Ferber writes that "declining positions and wages of all Americans means that white men are correct when they perceive themselves to be losing ground" (Ferber 2004: 228).

\section{Education and Gender}

In the United States Lindsey (2011) notes that "for whites, African American, and Latino, gender gaps favoring males in high school and college graduation rates largely disappeared by the 1990s; today the gender gap in both favor females" (Lindsey 2011: 313). In 1981, the percentage of white male and white female who completed high school was $89.7 \%$ to $89.9 \%$ respectively. By 1991 , the gap between white males and white females begins to widen with $92.7 \%$ of white males and $94.2 \%$ females. At the college level, in 1991 BA went to $26.5 \%$ white males and 26.9\% white females. By 2007 the gap between white male graduates and white female graduates was be $31.9 \%$ compared to $39.2 \%$ representing a $7.3 \%$ gap.

In Canada, Wotherspoon writes, "proportionately more men than women were enrolled in post-secondary programs until the mid-1980s, after which time the number of women has exceeded the number of men" (Wotherspoon 2014: 250). He notes that the ratio of female to male full-time undergraduates university students has risen in the mid -1970s until "women now constitute about $55 \%$ of all students in master's programs and just under half (47\%) of students in doctoral programs" (Wotherspoon 2014: 250). In a knowledge based society this can only mean that the unemployment rate for men without education or marketable skills may can continue to increase. Sweet and Meiksins (2017) question the assumption of a knowledge - based economy dependent on "highly educated technically sophisticated employees, rather than the low-skill workers needed by mass production industry" (Sweet and Meiksins 2017: 38). For Blau and Ferber (1992) historic trends, indicate economic cycles in which white, as well a black, males experience higher rates of unemployment. As they note "the blue-collar jobs and durable-goods manufacturing industries, which have a larger proportion of male workers are subject to greater cyclical variations in employment. Thus, men's employment tends to decline more in downturns" (Blau and Ferber 1992: 251).The 
central social and economic conclusion of the recession of 2008 is that males in post-modern society are becoming as Greig and Martino argue the "new disadvantaged".

\section{Conclusions}

Discussions of male privilege and power are often angry, hostile, blaming, and challenging to the self-esteem, pride and well-being of boys and men. For many, patriarchy, capitalism, socialism, communism, and racism are the social forces perpetuating male privilege and power and creating gender and racial inequality and discrimination. These social forces cannot be ignored, but should we ignore the values that individual and groups create to perpetuate inequality and discrimination? Nor can we ignore that the cultural and social changes in postmodern are encouraging men to challenge male instrumental roles and their resultant stoicisms rationalism and inexpressiveness. For example, Balswick (1988) argues, "men need to be liberated from the emotional hang ups that prevent them from becoming intimate in human relationships" (Balswick 1988: 9).

Many of the harshest critics of the inequalities in gender and race fail to acknowledge that all men, including white male, struggle to make sense of their failures, successes, disappointments, broken dreams, grief, accomplishments, pains, aging and disabilities. When sociologists examine such variable as life expectancy, violence, unemployment, and education, there is no clear and simple narrative about men and male privilege. Many sociologists are reluctant to examine the complexity of statistical data and public discourse concerning male status, power and privilege. Knuttila (2016) concludes his analysis of patriarchy and hegemonic masculinity by stating that "not all, or even most, males endorse or attempt to practice hegemonic masculinity. Many men, for example, may find themselves in economically subservient positions under the control of other men and without opportunities to express power, control, or domination" (Knuttila (2016: 161). Post-modernity is not an ideal social era and many academics, legislators, individuals and social activists advocate for greater gender and racial fairness, and equality. However, there are numerous historic examples in which dramatic cultural and social changes have resulted in the creation of "new" elites rather than the elimination of existing prejudices and discrimination. Today we may be witnessing, covert and overt signs, of a new form of prejudices and discriminations emerging against males. Is there a growing danger that the blaming and shaming by social critics of boys and men is contributing to "new" patterns of gender and racial discrimination and misandry?

\section{References}

Blau FD, Ferber MA (1992) The Economics of Women, Men, And Work. Englewood Cliffs, New Jersey: Prentice Hall.

Balswick J (1988) The Inexpressive Male. Lexington, Mass: Lexington Books. Collins R, Makowsky M (2010 The Discovery of Society. New York: McGraw Hill. 
Corneau G (1991) Absent Fathers, Lost Sons, The search for masculine identity. Boston: Shanbhala Publishing.

Farrell W (1993) The Myth of Male Power. New York: Berkley Books.

Ferber AL (2004) Racial warriors and Week-end warriors; The construction of masculinity in mythopoetic and white supremacist discourse. In PF Murphy (ed), Feminism \& Masculinities, 228-243. Oxford: Oxford University Press.

Fordhman S, Ogbu JU (2015) Black students' success: coping with the burden of acting white'. In R Arum, IR Beattie, K Ford (eds) The Structure of Schooling, Readings in the Sociology of Education. Los Angles: Sage.

Greig CJ, Martino WJ (2012) Canadian men and masculinities: historical and contemporary perspectives. Toronto: Canadian Scholars' Press Inc.

Hennessy T, Yalnizyan A (2009) Canada's 'he-cession': Men bearing the brunt of rising unemployment. Canadian Centre for Policy Alternative 19(4).

Hooks B (2004) The will to change; men, masculinity, and love. New York: ATRIA Books.

Kaufman M (1993) Cracking the armour: power, pain, and the lives of men. Toronto: Viking.

Kahn JS (2009) An Introduction to masculinities. Oxford: Wiley-Blackwell.

Knuttila M (2016) Paying for masculinity; Boys and Men Patriarchal Dividend. Halifax \& Winnipeg: Fernwood Publishing.

Kwan-Lanford D (2012) Racialized Masculinities in Canada. In JA Laker (ed) Canadian Perspectives on masculinities on men and masculinities, an interdisciplinary reader. Don Mills: Oxford University Press.

Lindsey LL (2011) Gender roles: a sociological perspective. Boston: Prentice Hall.

Morning A (2016) Race and ethnicity. In J Mange, R Arum, L Haney (eds) The Sociology Project 2.0: Introducing the Sociological Imagination New York: Pearson.

Morse GL (1996) The image of man: The creation of modern masculinity. New York: Oxford University Press.

Nathanson P, Young KK (2001) Spreading misandry: the teaching of contempt for men in popular culture. Montreal: McGill- Queen's University Press.

Payne L (1991) Crisis in masculinity. Wheaton, Ill: Crossway Books.

Perls TT, Fretts RC (2002) Why women live longer than men. In Frank Trovato Population and society: essential readings. Oxford: Oxford University Press.

Perry P (2015) Shades of white, white kids and racial identity in high schools. In R Arum, IR Beatrie, K Ford (eds) The structure of schooling, readings in the sociology of education. Los Angeles: Sage.

Statistics Canada (2015) Life expectancy at birth, by sex, by province, Table 102-0512 and Catalogue 84-537-XIE.

Sweet S, Meiksins P (2017) Changing contours of work: jobs and opportunities in the new economy. Thousand Oaks, California: Sage Publication.

Watson J (2000) Male bodies: health, culture, and identity. Buckingham: Open University Press.

Weber M (1947) The theory of social and economic organization. New York: The Free Press.

Wotherspoon T (2014) The sociology of education in Canada. Toronto: Oxford University Press. 